\title{
A REVIEW ON CHARACTERIZATION OF MICROORGANISM FROM
} MUNICIPAL WASTE

\section{BADWAIK SN ${ }^{1}$, UPADHAYAY $\mathrm{D}^{2}$, ANDHARE $\mathrm{P}^{2}$ AND PRAJAPATI $\mathrm{P}^{2 *}$}

1:PG student, Department of Microbiology, Parul Institute of Applied Science, Parul University, Po-Limda 391760, Ta- Waghodia, Dis- Vadodara

2: Assistant Professor, Department of Microbiology, Parul Institute of Applied Science, Parul University, Po-Limda 391760, Ta- Waghodia, Dis- Vadodara

*Corresponding Author: Dr. Priyanka Prajapati; E Mail: priyanka.mistry82141@paruluniversity.ac.in; Tel:

$+919913562946$

Received 24 ${ }^{\text {th }}$ Jan. 2021; Revised 27 $7^{\text {th }}$ Feb. 2021; Accepted $28^{\text {th }}$ March 2021; Available online $1^{\text {st }}$ April 2021

https://doi.org/10.31032/IJBPAS/2021/10.4.1055

\begin{abstract}
The municipal solid waste consists of household waste, industrial waste, and commercial. This waste classifies into organic and inorganic waste. The rate of solid waste generation and quantity in a given area are largely determined by the population and socioeconomic status of its residents, as well as the predominant commercial activity in that area. In soil there are 80 to $90 \%$ of microorganisms remain unidentified. The MSW contains the pathogenic microorganism and their presence increase the risk of causing diseases to human. Open dumping of solid wastes into a wetland, a waste course drain, or a burrow pit is a common form of disposal in developing countries, resulting in litter, an eyesore, and an odor nuisance. The open dumps risk the health and also reduce the aesthetic value of the surrounding. In municipal waste bacteria like Staphylococcus sp., Bacillus sp., Escherichia coli, Pseudomonas sp., Klebsiella sp., and fungi like Aspergillus niger, Aspergillus sp., Candida sp., are found which is harmful to both the human and the environment. There must be proper awareness should be created among the public regarding waste disposal and its management.
\end{abstract}

Keywords: Microorganism, Municipal Solid Waste (MSW), Human and Environment risk, and Solid waste management 


\section{INTRODUCTION}

Municipal solid waste (MSW), also known as litter or garbage in the United States and refuse in the United Kingdom. Municipal solid waste is a mixed bag of residential, commercial, institutional, and industrial waste. MSW, as described by the Environmental Protection Agency (EPA), does not include manufacturing, dangerous, or construction and demolition (C\&D) waste. This waste is mainly created by residential and commercial complexes. Municipal solid waste (MSW) generation is a worldwide problem. Municipal solid waste generators include residential, industrial, commercial, institutional, construction, demolition, municipal, and agricultural waste generators [1]. Municipal Solid Waste (MSW) is a form of waste that mainly consists of household waste (domestic waste), but may also include industrial wastes, construction and demolition debris, sanitation residue, and waste collected from streets by a municipality within a specific region [2]. Municipal solid waste is produced by human and animal activities and is discarded as unnecessary or unwanted waste. In the United States, municipal solid waste is referred to as litter or garbage, while in the United Kingdom, it is referred to as refuse or rubbish of everyday things that we use and discard. Solid, liquid, and gaseous waste are all forms of waste, with solid or semi-solid waste being the most common.

The MSW quantity is expected to rise rapidly as the country aims to become a developed nation by 2020 [3]. Rapid industrialization, growth of the population, economic growth and higher living standards in India have resulted in a rise in municipal solid waste $[\mathbf{4}$, 5]. Economic development, urbanization, and improved living conditions in developingcountry cities have increased the quantity and complexity of municipal solid waste. In most developing countries, the management of municipal solid waste produced by rapid urbanization has become a major concern for government agencies, pollution control agencies, regulatory bodies, and the general public [6, 7].

Microbial diversity research is important for understanding the microbial ecology of an ecosystem. The microbial community is one of the most difficult to identify due to its extensive phenotypic and genotypic diversity [8]. The soil serves as a reservoir for many plant and herb microbial communities that can produce co2 and nitrogen [9]. Soil microbial organisms account for a sizable portion of the organic matter on Earth. The significance of microorganisms in the preservation of human habitats on Earth is no 
longer debatable. Microorganisms include bacteria, archaea, yeast, fungi, algae, and protozoa. Microorganisms can coexist with humans in extreme conditions such as hot springs, miles deep in the ocean, within rocks, and at extremely cold temperatures [10].

Despite the fact that these biological species are thought to play an important role in the preservation of a healthy biosphere, 80 to $90 \%$ of microorganisms remain unidentified [3, 11]. Solid Waste Microflora (SWM) are microorganisms that live in solid waste, the most common of which are bacteria and fungi. By using waste components, this microorganism multiplies [12].

The involvement of pathogenic organisms in MSW increases the risk of pollution to humans and their ecosystems.

\section{TYPES OF WASTE AND ITS COMPONENTS}

Food waste, garbage, commercial waste, institutional waste, street sweeping waste, industrial waste, construction and demolition waste, and sanitation waste are all examples of MSW. MSW is comprised of recyclables (paper, plastic, glass, metals, and so on), toxic substances (paints, pesticides, recycled batteries, and medicines), and compostable organic matter (fruit and vegetable peels, food waste). Paper, fruit, yard trimming, and plastic are organic waste components of MSW, while metal and glass are inorganic waste components. The typical composition of MSW produced by Indian cities is approximately 41 weight percent organic, 40 weight percent inerts, and 19 weight percent potentially recyclable materials [13].

\section{SOLID WASTE GENERATION}

The rate of generation of solid waste and its quantity in a specific area are largely determined by the population and the socialeconomic status of its inhabitants, as well as the commercial activity that predominates in that area. In developing countries, open dumping of solid wastes into a wetland, a waste course drain, or a burrow pit is a common method of disposal that causes littering and produces an eyesore and odour nuisance. The wastewater produced by domestic sewage, agricultural processes, and industrial wastewater is directly destined to the coast without treatment, and this average domestic sewage contains organic matter, nitrogen and phosphorus, suspended solids, dissolved oxygen, and bacterial parameters (faecal coliform) [14].

The annual volume of solid waste produced has risen from 6 million tonnes in 1947 to 48 million tonnes in 1997 and 90 million tonnes in 2009 , with the figure potentially rising to 300 million tonnes by 2047 [15]. The amount 
of MSW generated per capita is projected to grow at a $1-1.33$ percent annual rate $[\mathbf{1 6}, \mathbf{1 7 ]}$. According to several researchers, MSW generation rates in small towns are lower than in metropolises, and the per capita MSW generation rate in India ranges from 0.2 to $0.5 \mathrm{~kg} / \mathrm{day}$.

The waste produced in India's urban areas is approximately 170,000 tonnes per day, or approximately 62 million tonnes per year, and this is often projected to rise by $5 \%$ per year due to population growth and changing lifestyles [13].

MSW production is projected to increase to 165 million tonnes by 2031 and 436 million tonnes by 2050. According to one estimate, India's waste production increased from 46 million tonnes in 2001 to 65 million tonnes in 2011 [12]. According to the EPA in 1989, only $10 \%$ of this MSW is recycled, while the remaining $80 \%$ is disposed of in landfills and $10 \%$ is incinerated. In low-income countries, the average solid waste generation rate is 0.4 to $0.6 \mathrm{~kg} /$ person/day, compared to 0.7 to 1.8 $\mathrm{kg} /$ person/day in fully developed countries.Massive amounts of waste are created every day in India's cities and municipalities. Urban solid waste has a high organic content, varying from 70 to 85 percent.

\section{MICROORGANISM IN MUNICIPAL WASTE}

Hoffmeister, D., Germani, J. C., and Van Der Sand, S. T. (2005) used PCR to determine the survival of potentially pathogenic bacterial species and the identification of enterotoxigenic Escherichia coli from compost. A total of 33 genera and 56 species were described during the isolation of 222 bacterial colonies. Bacillus, Escherichia, Enterobacter, and Pseudomonas are the most common genera [18].

According to Kalwasiska, A., and Burkowska, A. (2013), pathogenic species such as Pseudomonas aeruginosa, Staphylococcus aureus, Rhizopus microsporus, Aspergillus niger, and Aspergillus flavus, as well as natural microflora, are present in municipal facility air. According to their findings, the bioaerosol released by the municipal facility is the source of hemolytic bacteria, Pseudomonas aeruginosa, and Bacillus subtilis species that pose the greatest risk in the sorting facility, and the indoor air of the room is highly/moderately polluted. Salmonella, Clostridium perfringens, and coliform bacteria have been found in the soil at the operating landfill cell, which poses the greatest risk [19]. 
Chetan, D. M., Raghavendra, H. L., and Prithviraj, H. L. (2017) state that their primary goal is to isolate bacteria found in solid waste and determine their application. They collected the sample from the waste dumpsite between 2006 and 2009. During their investigation, they discover that microbial proliferation is influenced not only by $\mathrm{pH}$ and temperature but also by the season. Among the bacteria isolated from the dump were Arthrobacter spp., Bacillus spp., Escherichia coli, Klebsiella spp., Micrococcus spp., Proteus spp., Pseudomonas spp., Serratia spp., Staphylococcus aureus, Staphylococcus spp., and Streptococcus spp. According to the analysis of variation, there was no substantial difference in the number of bacteria and fungi at the 5\% level; however, there are significant differences in the number of fungi among the different sampling periods (season) at the 5\% level [12].

Iheukwumere, I., and Okezie, O. (2017) conducted a study to assess the prevalence of pathogenic bacteria and fungi in urban waste dump sites. They isolated Escherichia coli, Staphylococcus aureus, Klebsiellasp, Pseudomonas aeruginosa, Proteussp, Salmonella sp, Bacillussp, Aspergillus niger, Aspergillus flavus, Fusariumsp, Penicilliumsp, and Candidasp during their research. The study of variance showed that there was a substantial difference $(\mathrm{P}>0.05)$ in the occurrence of bacteria but no difference in the occurrence of fungal [5].

\section{EFFECT OF MUNICIPAL SOLID WASTE ON ENVIRONMENT}

Waste in dumpsites is routinely set on fire to minimize volume, and this activity contributes to air pollution in the largely residential area. The unregulated dumping of solid waste in open dumpsites causes significant environmental degradation, and over time these heinous dumps become mountain-like open dumpsites in the middle of residential neighborhoods, complete with odors, insects, and rodents [5]. There are problems of odor and leachate movement to receiving waters. The odor could be a major issue, particularly during the summer, when average temperatures in India will exceed $45^{\circ} \mathrm{C}$ [13].

These open dumps pose health risks and reduce the aesthetic value of the surrounding areas, as well as microbial pollution of soil and groundwater system [5]. Methane is released into the environment as perishable waste decomposes under anaerobic conditions in open dumps. Methane is a significant contributor to global warming which causes fires and explosions. In developing countries, former dump sites are 
often converted into farmlands with little care. Plants produced in such soils absorb toxicants such as metals, which accumulate in plant tissues [13].

According to the World Health Organization (WHO), environmental pollution causes onequarter of the diseases that people face today [5]. Once a year, open burning of MSW and tyres releases 22,000 tonnes of contaminants into the atmosphere around the metropolis [13]. The health effects of MSW include exposure to harmful chemicals through the air, water, and soil media, exposure to infection and biological pollutants, stress associated with odor, noise, vermin, visual pleasantness, the danger of tire explosions, and subsidence, spills, injuries, and transportation pollution. Water contamination by leachate can spread microorganisms and disease; enteric fever may be a common problem for people in developing countries, as many of them cannot afford to drill wells deep enough to succeed in modern aquifers [5].Tires at dumps accumulate water, which allows mosquitos to breed, raising the risk of diseases like malaria, dengue fever, and West Nile fever. Uncontrolled waste burning at dumpsites emits small particles, which are a major cause of respiratory disease and smog [13].
Several of the microorganisms such as Bacillus sp., Pseudomonas sp., Staphylococcus aureus, Aspergillus sp., [5, 19] present in compost are the most wellknown respiratory sensitizers, causing a variety of respiratory symptoms such as allergic rhinitis, asthma, and chronic bronchitis. High concentrations of soil, bioaerosols, and metals in sorting facilities cause itchiness in the skin, sore throats, and respiratory diseases [20]. Bad waste management has been related to a rise in nose and throat infections, respiratory problems, inflammation, bacterial infections, anemia, decreased immunity, allergies, asthma, and other infections [13]. The unethical disposal of untreated solid waste is not only hazardous to human health but also poses a threat to the ecological environment [21].

\section{MUNICIPAL SOLID WASTE MANAGEMENT}

There are no safeguards or operational controls for the disposal of municipal waste in low-lying areas, and as a result, MSW management is one of the major environmental problems of Indian megacities. MSW management tasks include waste generation, storage, collection, transition, and transport, as well as waste processing and disposal. In most cities, the 
MSW management system consists of only four operations: waste generation, collection, transportation, and disposal. As a result, MSW management necessitates adequate infrastructure, repair, and development activities.Because of the unplanned and continuous growth of the populated areas, this becomes increasingly costly and sophisticated. The overseeing municipal corporations are having difficulty delivering the required level of public service due to their weak financial situation [3].

Inadequate waste management and handling causes environmental degradation, habitat destruction, and poses major threats to public health. Strong urban waste management results in garbage composting in landfills, while waste management methods such as recycling and reclamation are advanced in industrialized communities.Municipal solid waste management options differ based on their origins and compositions or components. Landfilling, incineration, composting, source reduction, and recycling are all options (reuse, remanufacture, and reclamation) [5].

Solid waste management decreases or removes harmful environmental and human health effects, while also promoting economic growth and a higher quality of life.

\section{CONCLUSION}

The municipal waste consists of the pathogen which causes the diseases to the human and creates nuisance in the environment. The microorganism found in the waste, by which decomposition of perishable waste, methane is gas is creating a foul smell. Microorganism such as Staphylococcus aureus causes diseases like eczema, pediculosis, and mycosis. Bacillus sp. cause diseases like anthrax, food-borne infection, because of their heat-stable spore. The fungus like Aspergillus sp. cause bronchial and pulmonary diseases like aspergillosis. Candida sp. cause candidiasis. The increase in the population and improper solid waste management leads to environmental pollution and damage the health of the public. Therefore, proper waste management should be present and also there is a need to create awareness among the public regarding proper waste disposal. So that there will be a decrease in the diseases and also in environmental pollution.

\section{ACKNOWLEDGEMENT}

It's our privilege and honour to express our sincerest gratitude to the Parul University, Vadodara, Gujarat for providing me all the necessary support and facilities including state of the art infrastructural facilities with advanced technological scientific laboratories 
and everything else that was required to carry out this work.

\section{REFERENCES}

[1] Madhushree S, Pieter Van B; Integrated solid waste management: A perspective on Bangalore (India). CREED working paper series No. 24. March 1998: 277 295.

[2] Atalia K.R., Buha D.M et al: A review on composting of municipal solid waste. IOSR Journal of Environmental Science, Toxicology and Food Technology. May 2015; 9(5): 20-29.

[3] Saha A: Biochemical and molecular characterization of bacterial consortium of municipal solid wastes. $\mathrm{PhD}$ Thesis, University of Kalyani, West Bengal. July 2012.

[4] Balasubramanian M: Municipal solid waste management in India: status, problems and challenges. International Journal of Environment and waste management. January 2018; 21(4); 253 268.

[5] Iheukwumere I, Okezie O; Studies on the microbiology of municipal waste sites in Abia state. Academic Journal of Science. Jan 2018; 07(02): 155-164.

[6] Glawe, U., Visvanathan C: Domestic Solid waste management in South Asian Countries-A Comparative Analysis. In International Conference on Integrated Solid Waste Management in Southeast Asian Cities. September 2006; 5-7.
[7] Erdogan R., Zaimoglu Z et al: Applicability of leachates originating from solid-waste landfills for irrigation in landfill restoration projects. Journal of Environmental Biology. Sep 2008; 29(5): 779-784.

[8] Atalia K.R., Buha D.M. et al: Microbial biodiversity of municipal solid waste of Ahmedabad. Journal of Materials and Environmental Science. Mar 2015; 6(7): 1914-1923.

[9] Raja M., Praveena G. et al: Isolation and Identification of Fungi from Soil in Loyola College Campus, Chennai, India. International Journal of Current Microbiology and Applied Sciences. February 2017; 6(2): 1789-1795.

[10] Begum K, Juhara KM et al: Isolation and characterization of bacteria with biochemical and pharmacological importance from soil samples of Dhaka City.Dhaka University Journal of Pharmaceutical Sciences. June 2017; 16(1): 129-136.

[11] Saha A., Santra S; Isolation and characterization of bacteria isolated from municipal solid waste for production of industrial enzymes and waste degradation. Journal of Microbiology \& Experimentation. May 2014; 1(1): 1-8.

[12] Chetan D.M, Raghavendra HL et al: Isolation and Characterization of bacteria from solid waste. International journal of 
Research and Scientific Innovation (IJRSI).May 2017; 4(5): 63-68.

[13] Kumar S, Stephen R. S et al: Challenges and opportunities associated with waste management in India. Royal Society open science. February 2017; 4(3): 160764.

[14] Adebayo FO, Obiekezie, SO: Microorganisms in waste management. Research Journal of Science and Technology. January-March 2018; 10(1): 28-39.

[15] Gupta N, Yadav K et al: A review on current status of municipal solid waste management in India. Journal of Environmental Sciences. July 2015; 37: 206-217.

[16] Pappu A, Saxena M et al: Solid wastes generation in India and their recycling potential in building materials. Building and Environment. June 2007; 42(6): 2311-2320

[17] Sharholy M, Kafeel A et al: Municipal solid waste management in Indian cities. Waste Management. April 2007; 28: 459-467.

[18] Hoffmeister D, Germani J C et al: Characterization of bacterial population during composting of municipal solid waste. Acta Scientiae Veterinariae. August 2005; 33(3): 283-290.

[19] Kalwasińska A, Burkowska A: Municipal landfill sites as sources of microorganisms potentially pathogenic to humans. Environmental Science:

Processes \& Impacts. March 2013; 15(5): 1078-1086.

[20] Nkwachukwu O I, Chidi N I., et al; Issues of roadside disposal habit of municipal solid waste, environmental impacts and implementation of sound management practices in developing country "Nigeria". International Journal of Environmental Science and Development.December 2010; 1(5):409418 .

[21] Emmanuel U, Ifeanyichukwu I et al; Isolation and Characterization of Bacteria and Fungi Associated with Biodegradation of Municipal Solid Wastes in Abakaliki Metropolis, Nigeria. International Journal of Environment, Agriculture and Biotechnology. May-Jun 2017; 2(3): 1294-1304. 